\title{
Carnivalism and Engaging Journalism in the Current Affairs Podcasts in South Korea
}

\section{Chang Sup Park}

Department of Mass Communications, Bloomsburg University of Pennsylvania, 400 East 2nd Street, Bloomsburg, PA 17815, United States

\begin{abstract}
In this digital age, the means of journalism are being drastically reinvented and the character of news is being constantly reconstructed. This study examines the nature of podcast journalism recently emerging in South Korea, based on two unique concepts - "carnivalism" and "engaging journalism". A carnival creates an arena where free expression of non-legitimate voices could resist and mock the dominant power. This study finds that Korean podcasts tend to subvert a range of authoritative discourses and provide a journalism venue for comic criticism and emotional catharsis. Podcasts not only serve to lampoon the establishment, but also re-engage people as citizens who have been left largely disillusioned from mainstream news. This research argues that the discourse in the current affairs podcasts takes on the nature of "engaging journalism", which motivates ordinary individuals to engage in elite-challenging political action.
\end{abstract}

\section{Introduction}

Journalism based on new information technologies takes on diverse forms, such as online newspapers, Internet television, Internet radio, blogging, and podcasting. New forms of journalism has received enormous attention because of their potential to revise and renew the old-fashioned journalism $[1,2]$ by challenging the practices of traditional journalism. New journalism based on the Internet has also been hailed as a potential boost to "reengage an increasingly distrusting and alienated audience" [3].

This study centers on "podcast journalism" recently emerging in South Korea (here after Korea). The podcast refers to an audio or video file that can be downloaded and distributed to personal computers or portable devices, such as Apple iPads or smart phones. Since their advent in the early 2011, numerous podcasts specialized in currentaffairs have appealed to Korean people, especially young generations. Every week almost a thousand episodes of current affairs podcasts are being made in Korea and attract a significant portion of news consumers [4]. The current affairs podcasts in Korea are distinguished from traditional news forms, in that they center onexplicit satirical criticism toward political elites and the establishment [5,6]. As a result, current affairs podcasts are exercising a significant impact on the journalism of Korea [7].

Against this backdrop, this study focuses on the podcast syndrome in Korea and examines how it has successfully adopted innovative nature rarely found in traditional journalism. To date research has been scarce on the potential of podcasting as a journalism tool. The present research also investigates how current affairs podcasts serve both those who are enthusiastic about information seeking and those who are increasingly being alienated from mainstream media. To this end, the present research draws on Mikhail Bakhtin's unique idea, "carnvalism." A carnival creates an arena where free expression of non-legitimate voices could resist and mock the dominant power [8]. This paper contends that the current affairs podcasts in Korea demonstrate a great potential as a new form of journalism by combining new technological traits and carnivalistic content and by appealing to young generations' changing demands for information and news.For that purpose, this study conducts a case study about NaneunGgomsuda, one of the most prominent podcasts in Korea and then discusses theoretical implications of podcast journalism using the concept of "engaging journalism."

\section{Current Affairs Podcasts in South Korea}

Radio refers to the wireless transmission of signals, by modulation of electromagnetic waves with frequencies below those of light [9]. Over the last two decades, radio technology has dramatically advanced. Especially, the appearance of the 'Internet radio' in the mid-1990s was revolutionary. Internet radio has removed the spatial and temporal limits of traditional radio [10]. Internet radio, however, has lost its newsness since the introduction of podcast technology in the mid-2000s. Adam Curry, a former MTV video-jockey, first created podcasting technology, which helps provide great ease and flexibility in finding and downloading pre-recorded audio or video files. In June 2005, Apple Computer added the podcasting feature to its iTunes software, enabling both downloading and uploading usercreated podcasts [11].

Podcasts refer to digital files containing audio or video content that allow consumers to "time shift and place-shift their listening and viewing habits through the downloading of content onto a personal computer or a portable media player for immediate or future viewing" [12]. People usually download podcasts via an automated feed, such as Really Simple Syndication (RSS) feed, which allows users to receive the information they have chosen [13]. By their very structure, podcasts transcend spatial and temporal constraints, making it easy to listen to or view them whenever and wherever convenient.

In regard to the potential of the podcast as a new medium, we can think of three unique technological features. One of them is the timeshifting function - the ability to listen to podcasts when audiences choose [14]. In traditional radio, the listener has little control over what is provided or when they listen to programming. Podcasts can be downloaded to mobile devices and therefore can be consumed at

${ }^{*}$ Corresponding Author: Dr. Chang Sup Park, Department of Mass Communications, Bloomsburg University of Pennsylvania, 400 East 2nd Street, Bloomsburg, PA 17815, United States; E-mail: spark21@hanmail.net

Citation: Park CS (2016) Carnivalism and Engaging Journalism in the Current Affairs Podcasts in South Korea. Int J Journalism Mass Comm 3: 119. doi: http:// dx.doi.org/10.15344/2349-2635/2016/119

Copyright: () 2016 Park. This is an open-access article distributed under the terms of the Creative Commons Attribution License, which permits unrestricted use, distribution, and reproduction in any medium, provided the original author and source are credited. 
any place and time, even at an environment where Internet access is not possible [15]. Secondly, podcasts seek to deliver programming to small but highly attentive audiences. For example, some pastors use podcasts for sermons, creating so-called "godcasts." In this regard, the notion of podcasting is close to 'narrowcasting,' which opens door to programming that has been unthinkable and unsustainable under the traditional broadcast model [16]. Lastly, podcasting offers anyone who wishes to have her/his own show an opportunity to do so [17] Podcasting allow individuals to "create their own media environments - unique to each listener and unavailable to anyone else" [18].

A form of nontraditional radio, podcasting, has largely leveled off today in Korea. Since its introduction in the early 2011, over 4,000 podcast episodes are made and consumed each week. Especially, podcasts are receiving increasing attention as a journalism tool. A substantial number of podcasts in Korea focus on political or social affairs. Every week at least five current affairs podcasts are ranked among the "top 10 popular podcasts" in this country. NaneunGgomsuda ("I am a Petty-Minded Creep"), Korea's first president-bashing lampoon, recorded about six million downloads per episode [19]. This figure is amazing considering that the total population of Korea is 50 million. Even though podcast technology is revolutionary, its use as a journalism tool is rare in other countries.

This unusual popularity of current affairs podcasts in Korea is even posing a threat to mainstream news media, such as television news and newspapers. Research shows that mainstream news media are losing readership (viewership) and agenda-setting power since the introduction of podcasts in 2011 [19]. For instance, many politicians, pundits, and pollsters say unanimously that current affairs podcasts are gaining their importance as a new journalism channel [20] Current affairs podcasts are also successful in encouraging politically apathetic people as well as ordinary people. The podcasts played a crucial role in the 2011 Seoul mayoral election, by substantially contributing to the victory of little known civic activist, who beat his elite opponent that received complete support from most mainstream media [20,21]. Podcasts have been regarded as one of the most engaging media that help to reinvigorate people's interest in public issues $[20,22]$. This study aims to answer how Korean podcasts attract such an unexpected number of listeners and play a significant role as a new journalism form.

\section{Carnivalism}

Most podcasts focusing on current affairs in Korea are not easy to define with the elements of traditional journalism. They do not abide by the norms of traditional journalism, such as rigorous formality, objectivity, and seriousness [23]. Instead, many current affairs podcasts are full of humor, satire, and parody. Even they are not hesitant to spit out slangs or swear words, which are hardly acceptable in traditional journalism. This study defines such nature of Korean podcasts as carnivalism. Many podcast shows are rife with non-stop chats about public issues and criticisms towardthe establishment including politicians [21]. Ordinary citizens, especially young adults who cannot find outlets to vent their anger from depressing economic and political situations, are drawn to theunrestrained lampoons in podcasts to relieve their frustration and disappointment [5]

A carnival is basically an entertaining public square [24]. In a carnival, people seek fun and joy by participating in various activities and by communicating with others. Regardless of social status or economic class; anyone can join and enjoy a carnival. However, unlike common understanding, a carnival is not all beer and skittles; it is also a space for resistance. In other words, a carnival not only provides a space for festivity and laughter, but also creates an arena where people can resist dominant power with free expression of non-legitimate voices against governing elites. A carnival is a space to oppose the official hierarchy that presents the world as unified, ideal, and fixed [25]. Through a carnival, official hierarchies of order are ridiculed and the social and political authority is inverted. Bakhtin [26] said, "What was suspended in carnival first of all was hierarchical structure and all the forms of terror, reverence, piety, and etiquette connected with it." In a nutshell, a carnival can be conceptualized as a space where (1) critical inversion of official words and hierarchies, (2) suspension of hierarchical norms and prohibitions, and (3) creative disrespect for the establishment become possible [27].

Ata carnival, the expression of resistance employs very entertaining formats. Acarnival relies on several methods such as jests and insults directed toward political actors, satire and parody, the transgression of social mores, and the inversion or suspension of hierarchical norms $[26,28,29]$. Drawing on the literature, this study views humor, satire, and parody as the main components of carnivalism found in the current affairs podcasts in today's Korea.

Humor is "a mechanism that relieves the subject of the accumulated elements of aggressively hidden within the unconscious" [29]. Humor is a relief mechanism from a deep anxiety or repression and the need to escape from such a condition. From the past, political humor used to be "a familiar vehicle for expressing popular disdain and opposition against repressive regimes" [30]. Political humor as a reaction to the great concentration of power is a safe release from a superior force [31]. Political humor enables people to vent social and economic frustrations and thereby allows them to release suppressed desires and freedoms [30].

Satire is a discourse that people use to make fun of someone and relieve people from certain oppression [29]. Satire momentarily creates laughter and a sense of relief accompanied by the freedom from the oppressing subject. Satire creates "a space of freedom through this counter-hegemonic project raising the political consciousness of the disempowered people and taking part to an expression of resistance" [29]. A meaningful satirical discourse is one that mocks the existing rule and degrades the dominant hegemony. A satirical discourse becomes successful when it draws the hidden identity of oppression and reveals it at the center of public attention. Satire initiates laughter, fosters resistance, and makes people feel free from the ideological oppression of the dominant discourse.

Lastly, carnivalistic resistance is often expressed via parody. Parody is defined as "an imitation of the style of a particular writer, artist, or genre with deliberate exaggeration for comic effect". That is, parody is an imitation that is set against an original or falls far short of the real thing. According to Bakhtin [32], parody is a kind of double-voicing, as when a speaker acts out what another has said in a comic manner. Double-voicing deflates the seriousness of a statement thus inserting "a new semantic intention into a discourse which has, and which retains, an intention of its own" [32]. Political parody is often used for raising a counter meaning to the ruler's words and to ridicule the political agenda of the ruler [30]. A parody creator relies on the ruler's discourse but "introduces into that discourse a semantic intention that is directly opposed to the original one" [32]. As a result, the voice of the parody creator clashes with the voice of the ruler who controls the dominant discourse there by creating a tension between the two voices. 


\section{Carnivalism in NaneunGgomsuda}

This section examines how carnivalism was infused into NaneunGgomsuda, one of the most well-known podcasts in Korea. This show was aired from April 2011 to December 2012. This study chose to examine NaneunGgomsuda because the show has been evaluated as including enough carnivalistic content $[5,7,21]$. The show is also important in that it stimulates journalists to attend to and to reevaluate the rules and assumptions that dictate journalistic practice.

The show was recorded once a week in a small studio in Seoul, with four hosts attending. This show was a kind of role-playing performance. The four members had their own roles. The leader, Kim Ou-joon, was the owner of a political parody website. His main role was to lead and coordinate the show. Jung Bong-ju, a former lawmaker, played the most talkative character in the show. He habitually cut off the others midsentence and punctuated almost every statement with laughter. Choo Jin-woo, a reporter with the newsweekly SisaIN, was a character whose main job was to present newsworthy topics to the show. He often revealed political scandals rarely covered by the mainstream media. Kim Yong-min, a former radio commentator, took charge of two roles - vocal mimicry and parody song production. He regularly composed new parody songs about the former President Lee Myungbak to the tunes of church hymns.

The show was rife with humor. The four hosts constantly chuckled. They used their natural dialects based on their gut. The show favored everyday language of ordinary people. Complex jargons, difficult words, and elite words were hardly visible. For example, the following expressions were frequently heard at the show: "Pack your luggage" (quit this job), "His neck was cut" (he was fired), "He was bounced off" (He lost political power), "Shut up" (Be quiet), and "He ate up all" (He filled all the important governmental positions with his aides).

In addition to everyday language, provocative words were frequently used in this show. The four hosts were never hesitant in their word choice. Even expletives wereheard as often as in R-rated movies: "The situation is doggy mess," "fxxxing," "peel the pxxxx" "son of bitch" were often heard at the show. These curses and swears were usually directed toward the former President Lee, corrupt politicians, "political" prosecutors, and mainstream media journalists.

Jung: What are the public officials doing in this doggy nation? They do not listen to anybody. They just care themselves.

Kim Ou-joon: Uhm, each just strives to survive for oneself, never caring others, $f x x \times x \times x$.

Jung: That's why we cannot even dream collaboration between officials and government agencies.

Kim Ou-joon: Only President himself...

Jung: He damn decides all.

Kim Ou-joon: He used to do things all himself. (from episode 2, $12 \mathrm{May}$ 2011)

While humorous comments never stopped in the show, Naneun Ggomsuda essentially concentrated on creating an atmosphere of resistance, which is not the typical case in the mainstream media in Korea. At the introduction and ending of each episode, the four hosts shouted the catchphrase of the show: "Let's not be intimidated! Let's say whatever we want, even if we're thrown into jail tomorrow."

One prime example of resistance from the show is its intense focus on the scandals about the former President Lee and corrupt power elites. During the 2011 Seoul mayoral election, NaneunGgomsuda exercised its agenda-setting power with a number of scoops. For example, in the episode 12 , Choo reported that Na Kyung-won, the ruling party's candidate in the mayoral race frequented a luxury skin-care clinic where the annual membership fee is $\$ 90,000$. At an election in which the wealth gap between the rich and the poor was an important campaign issue, Choo's report resulted in playing a decisive role in drawing the attention of the electorate. Ms. Na sued the program for libel, but the prosecution found no evidence of Choo's guilt. Choo was also the first to report that President Lee had bought a very expensive lot to build his retirement residence, not in his name but in his son's name. Soon, this report developed into a big political scandal. Many political analysts voiced that NaneunGgomsuda overwhelmed the mainstream media during the election cycle [21].

Another important method of resistance in the show waists constant attempts to re-interpret major issues. With only four members, it was inevitable for the show to depend on the news stories already published in other media. However, the show raises questions to the explanations or analyses set up by politicians or mainstream media. Rather, it ferociously challenges dominant frames about an issue, by overturning, twisting, andre-investigating the issue.

The re-interpretation of a major issue was processed in three steps. First, the four hosts aggregated all available clues, contexts, and backgrounds regarding the issue. Second, they suggested several hypotheses based on their own coverage efforts. They often said, "We raise several scenarios about..." The last step was to conjecture the truth or real meaning of the issue: "There is enough circumstantial evidence to suggest..." Through this process, the show successfully revealed contradictions, conspiracy, and unreality, which often attested to the intrigue of the establishment regarding the issue.

The resistance in NaneunGgomsuda was accompanied bysatirical criticism. In June, 2011, the main opposition party and civic groups requested that the free lunch benefit should be given to all students in Seoul. At this, then-Seoul-Mayor Oh Se-hoon announced that he would hold a referendum for that issue, objecting to the opposition party's suggestion. NaneunGgomsuda satirized Oh'sattitude, pointing out that he was simply an avatar of the former President Lee because the President constantly objected to the expansion of social welfare.

Jung: Mayor Oh is in the same party as His Highness who also served as the Seoul mayor in the past. Therefore, we should say that Oh is a person as lofty as His Highness.

Kim Ou-joon: He is a complete successor of His Highness.

Jung: His Highness is pouring $\$ 18$ billion in restoring the four major rivers of Korea, which have had no problems so far.In a very similar way, Oh is also considering spending astronomical money in expanding the Han River in Seoul.

$\mathrm{Kim} \mathrm{Ou}$-joon: His Highness is a perfect role model of $\mathrm{Oh}$.

Parody was often employed as a rhetorical tool when the show reported news addressing the alleged nefariousness of the former President Lee. For instance, in every parody song, Lee was described as a petty-minded creep just like the title of the show. In many parodies, President Lee was portrayed as a person who always lies, hides something, and attributes blames to ordinary citizens not to himself: "As a President, I will do my best to ignore and distress citizens."

Carnivals have long been associated with resistance in human society. A brief look at history shows us that early carnivals were spaces for the public to express dissent to the established order [33]. As Turner [34] said, a carnival is an "anti-structural" sphere, 
where dominant social relations are inverted or leveled. Some of these notions have carried over into the current affairs podcasts of Korea, gratifying news consumers' desires for resistance toward the establishment. The effective application of carnivalistic techniques implies a shared understanding between podcast hosts and listeners.

\section{Engaging Journalism}

One prime mission of journalism is to undergird democracy by explaining complicated issues, events, and processes in timely, clear, unbiased, and fair language [35]. The mainstream media of Korea have been criticized for being slanted toward conservatism, unfair reporting, and manipulation of public opinion [36]. The mainstream media of Korea expanded their market share through close connection with the political power [37]. Top three conservative newspapers Chosun, Donga, and Joongang - occupy about $60 \%$ of the newspaper market of Korea. Two major TV stations - KBS and MBC, which are controlled directly and indirectly by the government, are extremely influential in the broadcast market. Without serious competition and explicit support from the political power, those big media in Korea have prospered even with unsatisfactory and biased news reporting [37].

Since the late 1990s, the Internet has created a breathing room for different and anti-government voices. A number of Internet-based media started playing an alternative role in Korean journalism. But the cyberspace had to suffer from the censorship by the government's "legal" and "administrative" actions. In this situation, critical citizens began to create another media channel that can represent their voice. Podcasts have appeared at this moment. As discussed earlier, podcasting is free from any regulation and convenient to upload and download news content. As a result, some politicians, former journalists, and civic activists have enthusiastically introduced their podcast shows and used them as a new journalism channel.

Considering such a background, it is not surprising that the discourse of podcasts as journalism is frequently organized around the idea of challenging mainstream journalism, chronicling perceived evidence of the news media's political bias, censorship or reporting inaccuracies. A number of podcasts see their shows as a critique toward mainstream media $[5,19]$. In this sense, podcasts are challenging the legitimacy of traditional news and mainstream media that have done a poor service to the public.

Drawing on the above analyses, the current study views that Korean podcast journalism resembles public journalism or citizen journalism. Public journalism is based on the assumption that journalism should help citizens' engagement in the public life. According to this concept, journalists should deliver stories that provide information that enables people to act as informed citizens. It is an important responsibility of journalism to take the initiative to report on major public problems in a way that advances public knowledge of possible solutions and helps people to participate in the public life. However, while the professional journalists generally remain the gatekeepers in news editing and publishing in public journalism, non-journalist experts are the major content producers in podcast journalism. In citizen journalism, ordinary people - individuals, citizen groups, or nonprofit organizations - are responsible for gathering, editing, and publishing content. In this model, professionals - both journalists and non-journalist experts - are not involved at all. However, the podcast journalism in Korea is different from citizen journalism because it is based on one-way delivery of news content made by people who possess expertise in specific areas. Also, either pubic journalism or citizen journalism does not contain carnivalism found in the currentaffairs podcasts in Korea.

This study suggests "engaging journalism" as a new theoretical framework to explain the nature of podcast journalism in Korea. In the face of the transforming media environment, journalism is compelled to provide "added value" to its audiences in addition to its original mission [39]. The popularity of the current affairs podcasts in Korea suggests that today's news should be both interesting and engaging.

Across the world, some journalism scholars and pundits deplore the trend that young people are turning out from the news [40-42]. They blame youth's disinterest in conventional news and bemoan their ignorance and charging them with apathy and laziness. However, such a claim is not based on solid evidence. As Katz writes, "for the young, culture is politics, personal expression and entertainment all fused together". Sometimes, entertainment plays an important role in young citizens' development of public awareness [43,44]. News is just one of many genres young generations use to make sense of the world. Wilson argues that young adults appreciate the sarcasm, irony, parody, and satire pervasive in social networking sites. Digital generations do not want to feel marginalized by mainstream news, which usually present information in a serious and conventional way.

The current-affairs podcasts in Korea is simultaneously informative and entertaining mainly thanks to their carnivalistic nature. Several scholars $[45,46]$ pointed out the inherent arbitrariness of the news/ entertainment. Such a distinction, in assuming the natural superiority of journalism over entertainment, fails to consider the important role the current-affairs podcasts might play as a purveyor of new types of news. Many podcasts seem to resist the binary distinction between news and entertainment, making the categorization largely ineffectual. Podcast hosts deliver news in their natural dialects, from their guts, which professional journalists wouldn't normally make it through the news making process. It is very likely that news content coated with humor, satire, and parody would interest more young generations to podcasts. Indeed, the four hosts of NaneunGgomsuda do not mind becoming clowns on the show as Jung said at an interview: "I'm a clown. I speak and act on people's behalf".

Many other current-affairs podcasts of Korea also provide programs that are politically funny and drip with satire and parody that many young people appreciate [21]. They provide comedic interpretations on a wide range of public affairs topics. They offer both entertainment and news. By using comedy and satire to mock the invested power elites, current-affairs podcasts tell the audience more about the world than many of the legitimate news outlets do [21].

Furthermore, many current-affairs podcast offer a satirical critique of various elements of Korean democracy, politics, and journalism. They present a competing message type to more traditional forms of news programming. More specifically, the current-affairs podcast in Korea are less obsessed with transmitting known facts and less committed to the formal routines of traditional reportage, but more concerned with motivating people engage in the democratic process by providing substantial and unique explanation about the context and background regarding an issue or event. In short, the current study documents how the current-affairs podcast are showing the nature of "engaging journalism." The uptake of current affairs podcasts demonstrates that "engaging journalism" is shaping in Korea. 
Citation: Park CS (2016) Carnivalism and Engaging Journalism in the Current Affairs Podcasts in South Korea. Int J Journalism Mass Comm 3: 119. doi: http:// dx.doi.org/10.15344/2349-2635/2016/119

Page 5 of 6

\section{Discussion}

Today, Korea is passing through a revolutionary change in media development. Since the early 2011, numerous podcasts specialized in public affairs and politics have expanded their realm, sometimes jeopardizing the mainstream media power that has been stable and strong over the last six decades in Korea. This research sought to investigate how the podcast has become a promising journalism tool, based on two unique concepts - carnivalsim and engaging journalism. This study, via a case study of NaneunGgomsuda, found that carnivalism and engaging journalism are the main characteristics of numerous current-affairs podcasts in Korea.

Through the use of comedic techniques such as humor, parody and satire, the discourse in podcasts transgresses existing social and cultural hierarchies. Satiric and ludicrous in nature, podcasts playfully subverts a range of authoritative discourses and provides a vehicle for both comic criticism and emotional catharsis. Carnivalistic properties have scarcely been found in the mainstream media of Korea, which have long been criticized for their abuse of media power and indifference in citizens' authentic demands. It is very likely that the new journalism form created by the current-affairs podcasts provides a new momentum to the existing journalism routines and practices of Korea [47].

The podcast syndrome in Korea should be interpreted not only as a challenging the legitimacy of serious news but also as challenging established journalism. The uptake of current-affairs podcasts raises a question about what journalism should look like today. The currentaffairs podcasts stimulate journalists to think about what it means to be a journalist and what weaknesses should be removed in aging journalistic conventions. This is, of course, just the beginning of the conversation regarding the future of journalism.

The carnivalistic podcasts of Korea also should receive scholarly attention in terms of "engaging journalism."In podcasts, news is both engaging and legitimate. The old technology radio has successfully transformed into an alternative medium by combining old and new technologies and carnivalistic content and by enabling individual users to take advantage of such carnivalistic content for the purpose of elite-challenging participation. Podcasts not only serve to lampoon the establishment, but also, in doing so, provide news consumers an alternative news venue. Satire, parody, and humor are welcomed as forms of resistance against the absurdity of power elites. An understanding of humor, satire and parody requires intense engagement on the part young audiences.

The present study argues that the uptake of current-affairs podcasts offers journalists opportunities to reflect on current industry assumptions, identities, and practices. In other words, podcasts provide journalists a reflective lens by which they can examine the rules and conventions of their professional practice. While a departure from typical journalism routines might be troubling, podcasts might shed light on ways to develop new forms of journalism that appeal to audiences.

This study suggests that future research needs to develop theories surrounding the study of carnivalistic podcasting. Even though this study point to signs that the podcast is actually changing the nature and practice of journalism, some people may believe that the podcasting craze could be a passing fad. Therefore, following studies should examine more nuanced characteristics of carnivalistic podcasts in relation to the development of journalism.

\section{Competing Interests}

The authors have no conflict of interest to disclose.

\section{References}

1. Stovall JG (2004) Web journalism: Practice and promise of a new medium. Boston,MA: Pearson.

2. Boczkowski PJ (2002) The development and use of online newspapers: What research tells us and what we might want to know. In: Lievrouw LA and Livingstone S (eds) Hand book of new media: Social shaping and consequences of ICTs. London: Sage.

3. Pavlik J (2001) Journalism and New Media. New York: Columbia University Press.

4. Podbbang (2014).

5. Lee K, Lee Y, Hwang K, Chae J, Cheon H, et al. (2012) A critical analysis of $<1$ am a Weasel $>$ and its implications. Korea Association for Communication and Information Studies 58: 74105.

6. You CS (2011) NaneunGgomsuda: A new phenomenon in the social network age. PoliNews.

7. Baek C (2012) Podcast Heyday. Kyunghyang Weekly.

8. Bakhtin M (1984a) Rabelais and his world. Bloomington, IN: Indiana University press.

9. Hartley J, Notley TM (2005) User-led Content and Self-creating Communities: History Repeating Itself? Understanding "Internet Radio" in the Context of the Development of Radio.Radio in the World: Radio Conference 2005, August 2005, RMIT University, Melbourne.

10. Menduni E (2007) Four steps in innovative radio broadcasting: From QuickTime topodcasting. Radio Journal: International Studies in Broadcast \& Audio Media 5: 9-18.

11. Apple Computer (2005c) iTunes podcast subscriptions top one million in first two days (30 June 2005).

12. Haygood DM (2007) A status report on podcast advertising. Journal of Advertising Research 47: 518-523.

13. Chadha $M$, Avila A, Gil de Zúñiga $H$ (2012) Listening in: building a profile ofpodcast users and analyzing their political participation. Journal of Information Technology \& Politics 9: 388-401.

14. Duncan NB, Fox MA (2005) Computer-aided music distribution: The future of selection, retrieval and transmission. First Monday 10: 4 .

15. Dotto L (2005) Plugging into Podcasting's Potential: iPod Purveying. Toronto Star 30: D1.

16. Priestman C (2004) Narrowcasting and the dream of radio's great global conversation. Radio Journal: International Studies in Broadcast \& Audio Media 2: 77-88.

17. Affleck AJW (2005) Podcasting: The people's radio. TidBits.

18. Nason P (2005) Is Podcasting the New Radio? Washington Times, 7.

19. Choi S, Lim C (2013) Analysis of the Relationships between National TV News, Twitter of the Seoul Mayoral Candidates, and 'NaneunGgomsuda' during the 2011 Seoul Mayoral Election. Broadcast \& Communication 14: 5-35.

20. Hankyoreh (2011)The meaning of Seoul mayoral election.

21. Lee $Y$ (2012) Re-examining Naneun Ggomsuda. Seoul, South Korea: Culture \& Science. 
Citation: Park CS (2016) Carnivalism and Engaging Journalism in the Current Affairs Podcasts in South Korea. Int J Journalism Mass Comm 3: 119. doi: http:// dx.doi.org/10.15344/2349-2635/2016/119

22. Kim J (2012) Evolve into Homo Smartcus. Seoul, South Korea: Haenam.

23. McQuail D (2010) McQuail's mass communication theory. Thousand Oaks, CA: Sage.

24. Crossley N, Roberts M (2004) After Habermas: New perspectives on the public sphere. London: Blackwell.

25. Bakhtin M (1984) Rabelais and his world. Bloomington, IN: Indiana University press.

26. Bakhtin M (1963) Problems of Dostoevsky's poetics (Edited and translated by Caryl Emerson). Minneapolis, MN: University of Minnesota Press.

27. Stallybrass P, White A (1986) The politics and poetics of transgression Ithaca, NY: Cornell University Press.

28. Foot K and Schneider S (2002) Online Action in Campaign 2000 An Exploratory Analysis of the U.S. Political Web Sphere. Journal of Broadcasting \& Electronic Media 46: 222-244.

29. Mascha E (2008) Political satire and hegemony: A case of "passive revolution" during Mussolini's ascendance to power 1919-1925. Humor 21 $69-98$

30. Badarneh M (2011) Carnivalesque politics: A Bakhtinian case study of contemporary Arab political humor. Humor 24: 305-327.

31. Schutz CE (1977) Political humor. Cranbury, NJ: Associated University Press.

32. Bakhtin M (1984b) Problems of Dostoevsky's Poetics. Minneapolis, MN University of Minnesota Press.

33. Waterman S (1998) Carnivals for elites? The cultural politics of arts festivals. Progressin Human Geography 22: 54-74.

34. Turner VW (1982) Celebration: Studies in festivity and ritual. Washington, DC: Smithsonian Institution Press.

35. Downie L, Schudson M (2009) The reconstruction of American journalism New York: Columbia University Graduate School of Journalism.

36. Kim K (2005) The effects of Internet on the participation in collective action:Focusing on "2002 Candle-Light Demonstration." HankookSahuehak, [Korean sociology] 40: 183-211.

37. Kim S (2010) Media Market and Publicness. Seoul, South Korea: Hanul.

38. Chon K, Chang I (21 October 2011) NaneunGgomsuda rocks politics. Sisaln, 215.

39. Heikkilä H, Ahva L (2015) The Relevance of Journalism: Studying News Audiences in a Digital Era. Journalism Practice 9: 50-64.

40. Blumler JG (2011) Foreword: The two-legged crisis of journalism. In Franklin B (ed)The Future of Journalism. London, UK: Routledge.

41. Starr $P(2012)$ An Unexpected Crisis: The News Media in Postindustrial Democracies. The International Journal of Press/Politics17: 234-242.

42. Young S (2009) The Decline of Traditional News and Current Affairs Audiences in Australia. Media International Australia, Incorporating Culture \& Policy131: 147-159.

43. Barnhurst KG (1998) Politics in the Fine Meshes: Young Citizens, Power, and Media. Media, Culture \& Society 20: 201-218.

44. Calavita M (2004) Idealization, Inspiration, Irony: Popular Communication Tastes and Practices in the Individual Political Development of Generation X'ers. Popular Communication 2: 129-151.

45. DelliCarpini MX, Williams B (2001) Let Us Entertain You: Politics in the New Media Environment. In: Bennett B and Entman R (eds) Mediated Politics: Communication in the Future of Democracy. New York: Cambridge University Press

46. Pauly J (1988) Rupert Murdoch and the Demonology of Professional Journalism. In: Carey J (ed) Media, Myths and Narratives. Thousand Oaks, CA: Sage.

47. Hoffman LH, Young DG (2011) Satire, Punch Lines, and the Nightly News: Untangling Media Effects on Political Participation. Communication Research Reports 28: 159-168. 